\title{
MOVEMENT TRANSFORMATION IN GAYO SYNTAX
}

\author{
Tri Murni, Robert Sibarani, Eddy Setia, Gustianingsih \\ Faculty of Cultural Sciences \\ University of Sumatera Utara, Medan, Indonesia \\ Email: tri.murni.iy@gmail.com
}

Received: 16 December 2018

Accepted: 20 February 2019

\begin{abstract}
The purpose of this study is to present syntactic descriptions of how movement transformational rules apply in Gayo syntax and to examine the status of movement transformational rules in Gayo language (henceforth $\mathrm{GL}$ ) in the theoretical framework of Transformational Linguistics (TL) proposed by Chomsky $(1965,1981)$ and Suhadi $(2018)$. In this theory there are three kinds of syntactic rules: Movement Rule, Deletion Rule and Substitution Rule. The discussion focuses on Movement Transformational Rules in GL. Transformation is the inter-related process between the deep structure and the surface structure of a sentence by the application of one or more transformational rules. The method used in this study was descriptive qualitative approach as noted by Martin (2004). Descriptive research is to portray accurately the characteristics of a particular situation or group or individual with or without special initial hypotheses about the nature of these characteristics. Thus, descriptive research design was applied to give a detail description of a certain case accurately. The data were analyzed from two angles: the application and the status of movement rules in $\mathrm{GL}$, which can be compulsory, optional, and restricted. The data of this research derived from some sentences in the folklore story written in GL and the invention of the writer herself as the native speaker of the language. The finding shows that all the twelve kinds of movement transformational rules proposed by Suhadi (2018) are relevant to apply in $\mathrm{GL}$. After the application of movement rules, the main finding is on the status of movement transformational rules in $\mathrm{GL}$ in which it is found that four movement rules are compulsory, eight are optional and there is no restricted rule in the language.
\end{abstract}

Keywords: transformational linguistics, movement transformational rule, compulsory, optional, restricted.

\section{INTRODUCTION}

Gayo is a language used in central part of Aceh province, Sumatra, Indonesia. According to Eades (2005: 4) Gayo language (GL) is the form of Malayo-Polynesian language which is grouped in Austronesian, like Taiwan and Philippine language. The GL is used as daily communication among societies, in family ceremonies and in traditional meetings. Several researches about GL have been conducted by Indonesian researchers such as Shaumiwaty (2012) in her desertation entitled Phonology of Gayo Language: An Analysis of Generative Phonology. Zainuddin (2012) also wrote a dissertation entitled Morphological System of Gayo Language: Transformational Generative Analysis. Furthermore, some researches have 
also been conducted by foreigners such as Eades (2005) in his work entitled Gayo Grammar: Language of Aceh, Sumatra. Radford (1988) explained that Grammar was considered to consist of a set of phrase structure rules which generate phrase markers called Deep Structure (DS), and a set of transformational rules which perform various types of operation on these Phrase Markers to derive appropriately modified Phrase Markers called Surface Structure (SS). Transformation is known as being inter-related between the deep structure and the surface structure by a set of transformational rules. In Transformational Grammar, every well-formed sentence is generated from the deep structure into the corresponding surface structure through one or more syntactic transformations. Basically, there are three kinds of syntactic transformation: (1) movement transformation, (2) deletion or insertion transformation, and (3) substitution transformation. In this research, the writer describes only about syntactic movement transformation of GL. This study is important to do because there was no work written earlier, which is related to the analysis of Gayo syntax by applying the theory of Transformational linguistics in terms of movement transformation.

\section{Theoretical Background}

According to Ouhalla (1999) Movement Transformation or Displacement is a syntactic transformation in which the process is by moving a constituent from one position to another. Suhadi (2018: 104) notes that there are twelve kinds of movement transformational rules as presented in the following sentences either in labeled brackets or tree diagrams.

\subsection{Affix Hopping Transformation}

Affix hopping $(\mathrm{AH})$ movement transformation is a process of moving the tense element to the main verb or to the operator (first auxiliary) to provide a tensed verb phrase.

(1).
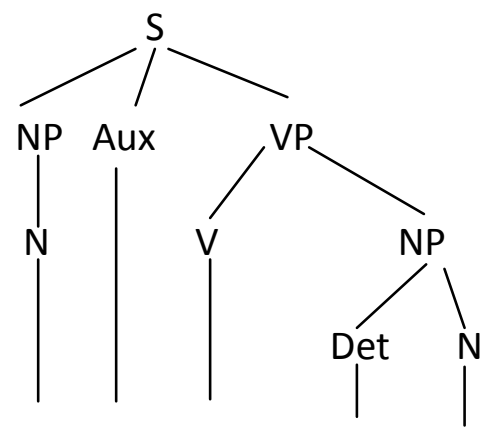

DS: He past dominate the debate.

$\mathrm{AH}$ : He dominated the debate.

SS: $\quad$ He dominated the debate.

\subsection{Aux Movement Transformation (Aux Raising)}

Aux movement transformation (Aux Raising) is a process of moving an operator (the first auxiliary) to the initial position of a sentence to express an interrogative sentence. Aux raising is a sensitive transformation because the DS is provided with $Q$ which means that it is in the question form. 
(2). Shall we go home?

$\begin{array}{ll}\text { DS (Q) } & : \text { we Present shall go home } \\ \text { Affix Hopping } & : \text { we shall go home } \\ \text { Aux Movement } & : \text { shall we go home } \\ \text { SS } & : \text { Shall we go home? }\end{array}$

\subsection{Wh-movement Transformation}

Wh-movement transformation is a process of the movement of a question word to the position of Comp. Comp is an empty category in the initial position of every clause which is provided for the direction of the movement of a wh-phrase in this respect. The movement of a wh-phrase to the Comp position is compulsory because in English a wh-word cannot be at the end of a clause as found in some Asian languages like Indonesian.

(3). We know what your name is.

DS

Wh-Movement

SS
: [We know [Comp [your name is what]]]

: [We know [Comp what [your name is $\mathrm{t}]$ ]]

: We know what your name is.

\subsection{Dative Movement Transformation}

Dative movement transformation is an indirect object of a ditransitive verb and it is characterized by its function as a recipient. An indirect object normally occurs after a direct object but in many instances an indirect object is used before a direct object, which is considered simpler as it is used without preposition. The sentence Dad gave Mom money is simpler and more widely used than Dad gave money to Mom. Thus, the former is the surface structure and the latter is the deep structure. Observe the process of the transformation of the above sentence in (4).

(4).

DS : [CP [IP Dad gave [NP money [PP to Mom]]]]

Dative Move. : [CP [IP John gave [NP Mom [NP money]

SS : Dad gave Mom money.

\subsection{Passive Movement Transformation}

In the first version of Chomsky's theory (1957), a passive sentence was derived from the corresponding active by applying an optional transformational rule with the provision of a formula involving Structural Description (SD), Structural Index (SI) and Structural Change (SC) in the process of the transformation. A passive sentence is derived from the corresponding active, which constitutes the DS. Thus, the DS of such a passive sentence as The play was written by Shakespeare is Shakespeare wrote the play, which has undergone syntactic transformation as in (5).

(5)

DS : Shakespeare past wrote the play

Passive Transf. :

$\begin{array}{llcclc}\text { SD } & : & \text { NP1 } & \text { Aux } & \text { V } & \text { NP2 } \\ \text { SI } & : & 1 & 2 & 3 & 4 \\ \text { SC } & : & 4 & 2+\text { be } & 3+e n & \text { by+1 }\end{array}$

SS : The play was written by Shakespeare. 


\subsection{Topicalization Transformation}

Topicalization transformation is a process of adopting the object of a sentence as the topic; that is by the process of movement transformation to topicalize the object by moving it to the initial position.

(6). Pancake, he likes very much.

DS : He likes pancake very much

Topicalization :

$\begin{array}{llllll}\text { SI } & : & 1 & 2 & 3 & 4 \\ \text { SC } & : & 3 & 1 & 2 & 4\end{array}$

SS

: Pancake, he likes very much.

\subsection{Particle Movement Transformation}

Particle is derived from a preposition but it has lost its former meaning and features as a preposition. It has fused its meaning much to a verb and it functions as an adverb. The position of a particle is mobile depending on the object following it. If the object is a simple NP, the particle may optionally be moved after the NP as in (7).

(7). John carried the job out.

DS
$\begin{array}{llllll}\text { Particle Move. : } & \downarrow & \downarrow & \downarrow & \downarrow & \downarrow \\ \text { SI } & : & 1 & 2 & 3 & 4 \\ \text { SC } & : & 1 & 2 & 4 & 3 \\ \text { SS } & & \text { : John carried the job out. }\end{array}$

\subsection{Relative Movement Transformation}

Relative movement transformation is compulsory when it is not in subject position. It should be moved to Comp in the initial position of a clause.

(8). This is the book which he has read.

$\begin{array}{ll}\text { D-Structure } & :[[\text { This is the book] [Comp [he has read the book]]] } \\ \text { Relativization } & : \text { [[This is the book] [Comp [he has read which ]]] } \\ \text { Relative Movement } & : \text { [[This is the book [which [he has read } t]]] \\ \text { S-Structure } & : \text { This is the book which he has read. }\end{array}$

\subsection{Premodification Transformation}

The unmarked position of a noun modifier in English precedes the noun modified as in $a$ new building although in certain conditions it occurs after the noun as in the example given and in other certain conditions it may be used optionally either as pre-modifier or postmodifier as in The time misspent is the time lost or The misspent time is the lost time. As the unmarked order is modifier + modified, the construction of modified + modifier must undergo transformation as (9).

(9). Flying planes can be dangerous.

$\begin{array}{ll}\text { DS } & : \text { [CP [IP planes flying] [CP [IP can be dangerous]]] } \\ \text { Premodification } & : \text { [CP [IP flying planes] [CP [IP can be dangerous]]] } \\ \text { SS } & : \text { Flying planes can be dangerous. }\end{array}$ 


\subsection{Adjective Preposing Transformation}

Adjective pre-posing transformation is an optional rule. It is generally used in speech in a certain style to emphasize the adjective phrase in the subordinate clause with the conjunction though.

(10). Very pretty though she is, Jim will not marry her.

DS : Though she is very pretty, Jim will not marry her.

Adjective Preposing : very pretty though she is, Jim will not marry her

SS $\quad$ : Very pretty though she is, Jim will not marry her.

\subsection{Verb Preposing Transformation}

A verb phrase may also be preposed if required to emphasize the meaning but it is limited to the type of verb phrase in the progressive form.

(11). Wearing blue jeans I think they are.

\section{DS}

Verb Pre-posing

SS
: I think they are wearing blue jeans.

: wearing blue jeans I think they are.

: Wearing blue jeans I think they are.

\subsection{Extra-position Transformation}

Extra-position transformation is a process of movement transformation in which the word order of a sentence is altered from an unmarked position to a marked position resulting in a discontinuity. The extraposed constituent is separated from its governor by one or more words that dominate its governor. Extraposition transformation is generally optional; however, the extraposed version of a sentence is sometimes preferred. The following pairs of sentences illustrate unmarked word order and are followed by the corresponding sentences with extraposition.

Extraposition of relative clause out of subject:

(12.a). DS : The boy who suffered from jaundice left home.

(12.b). SS : The boy left home who suffered from jaundice.

Extraposition of relative clause out of object:

(13.a). DS : The lecturer gives us materials that we don't like in every meeting.

(13.b). SS : The lecturer gives us materials in every meeting that we don't like.

\section{Research Method}

This study used descriptive qualitative method proposed by Matin (2004: 70) who notes that "Descriptive Research Design is to portray accurately the characteristics of a particular situation or group or individual with or without special initial hypotheses about the nature of these characteristics. Studies having this purpose are known as descriptive studies". Thus, descriptive research design was applied to give a detail description of the cases of movement transformational rules in GL accurately. The data were taken from some relevant sentences in folk story in Gayo language written by Kadir (1981), besides some sentences invented by the writer herself as a native speaker of the language. The data were analyzed from two aspects: the application of movement rules in GL and the status of movement rules 
whether it is compulsory, optional or restricted in the language. Compulsory rule is a syntactic rule applied to the DS of a sentence and if the rule is not applied it will lead to an unacceptable sentence. Optional rule is a syntactic rule whose application is optional and the result of either one will lead to an acceptable sentence. Restricted rule is a syntactic rule which is restricted to apply to the DS of a sentence due to a certain condition although the rule may also apply in a certain other condition.

\section{Discussion}

The discussion in this section focuses on two main aspects: the application of movement transformational rules in $\mathrm{GL}$ and the examination of the status of movement transformational rules in the language. The application of movement rules in $G L$ is based on the theory presented earlier which covers twelve kinds of movement rules and the examination of the status of movement transformational rules covers three possibilities: compulsory, optional and restricted as presented below.

\subsection{Affix Hopping Transformation}

Affix hopping transformation applies in GL as a compulsory rule; that is to combine prefix $m u$-, or bersi- with the verb to form a VP.

(14.a). Wè tengah mu+jerang jantar.

He/she is cooking vegetable'

DS : we tengah mu+ jerang jantar

'He/she is cooking vegetable'

$\mathrm{AH}$ : we tengah mu-jerang jantar.

'He/she is cooking vegetable.'

SS : We tengah mujerang jantar.

'He/she is cooking vegetable.'

When the affix mu- is not conjoined with the verb, the result is unacceptable as in (14.b).

DS : We tengah mu+, jerang jantar

'He/she is cooking vegetable'

AH : Not applied.

SS : *Wè jerang jantar.

*`He/she cook vegetable’

The same happens in (14.c) when the prefix bersi- is conjoined with the verb, the result is acceptable; but if it is not conjoined with the verb, the result is ruled out as in (14.d).

(14.c). Pakea ara bersientongen i empus.

'They are visiting each other in the garden.' 
DS : Pakea ara bersitentongen i empus

AH : Pakea ara bersitentongen i empus.

SS : Pakea ara bersientongen i empus.

'They are visiting each other in the garden.'

(14.d).

DS : Pakea ara bersitentongen i empus

$\mathrm{AH} \quad$ : Not applied

SS : *Pakea ara entongen i empus

*'They are visit each other in the garden.'

\subsection{Aux Movement Transformation}

Auxiliary movement transformation in GL is a compulsory rule by using the word ara ke after the auxiliary and closed with a question mark (?) to express an interrogative sentence.

Ara ke wè mu empus?

'Does he/she have a garden?'

DS (Q) ? : Wè ara ke mu empus?

'he/she does have a garden'

Aux Movement: ara ke wè mu empus?

'Does he/she have a garden?'

SS

: Ara ke wè mu empus?

'Does he/she have a garden?'

When the rule is not applied, the result is unacceptable as in (15.b). (15.b).

DS

: Wè ara ke mu empus

'he/she does have a garden'

Aux Move. : Not applied.

SS

: *Wè ara ke mu empus?

*'he/she does have a garden?’

\subsection{Wh-movement Transformation}

Wh-movement transformation in $\mathrm{GL}$ is also a compulsory rule. It means that the application of the syntactic rule is compulsory to be applied to the DS as in (16.a) and if the rule is not applied it will lead to an unacceptable sentence (16.b).

(16.a). Wè betèhe sana si iperene. 'He/she knew what is he/she said'

DS : [wè betehe [Comp [wè mumeren sana]]]

[he/she knows [Comp [he/she says what]]]'

Wh-move. : [wè betehe [Comp sana [si iperene $t$ ]]] 
'he/she knows what he/she said' $t$

: Wè betèhe sana si iperene.

'He/she knows what he/she said'.

(16.b).

DS

: [wè betehe [Comp [wè mumeren sana]]]

[he/she knows [Comp [he/she says what]]]'

Wh-move. : Not applied.

SS $\quad$ : *Wè betehe wè mumeren sana.

$\mathrm{He} / \mathrm{she}$ knows he/she says what'.

\subsection{Dative Movement Transformation}

Dative movement transformation in GL is an optional rule to be applied to the DS as (17.a) and when the rule is not applied the sentence will remain acceptable as (17.b).

(17.a). Ama munosah Uwin sen.

'Father gave Uwin money.'

DS $\quad:$ [CP [Ama munosah sen ku Uwin]]

'Father gave money to Uwin.'

Dative M. : : Ama munosah Uwin sen.

'Father gave Uwin money.'

SS : Ama munosah Uwin sen.

'Father gave Uwin money.'

(17.b). Ama munosah Uwin sen.

'Father gave Uwin money.'

DS $\quad:$ [CP [Ama munosah sen ku Uwin]]

'Father gave money to Uwin.'

Dative Move. : Not applied

SS : Ama munosah sen ku Uwin.

'Father gave money to Uwin.'

\subsection{Passive Movement Transformation}

Passive movement transformation in $\mathrm{GL}$ is an optional rule. A passive sentence is derived from the corresponding active, which constitutes the DS. Thus, the DS of a passive sentence is the active form which has undergone the process of syntactic transformation. It does not matter whether the rule is applied or not as either result will be an acceptable sentence as in (18).

(18). Rom i+tatang abang.

'Rice is lifted by brother.'

DS : Abang munatang rom.

'Brother lifts rice'

Passive Move.:

$\begin{array}{ccccc}\mathrm{SD} & : & \mathrm{NP1} & \mathrm{mu}+\mathrm{V} & \mathrm{NP2} \\ \mathrm{SI} & : & 1 & 2 & 3 \\ \mathrm{SC} & : & 3 & \mathrm{i}-\mathrm{V} & 1\end{array}$




\subsection{Topicalization Transformation}

Topicalization transformation in $\mathrm{GL}$ is an optional rule because it is used only when the native speaker of the language wishes to use the object as an important theme. If the rule is not applied, the result will be acceptable as the form of the DS (19).

(19). Kupi, pakea rejen pedi.

'Coffee, they like very much.'

DS : Pakea rejen pedi kupi.

'They like coffee very much .'

Topicalization :

$\begin{array}{lcccc}\text { SD : } & \text { NP1 } & \text { V } & \text { NP2 } & \text { Adv } \\ \text { SI : } & 1 & 2 & 3 & 4 \\ \text { SC: } & 3 & 1 & 2 & 4\end{array}$

: Kupi, pakea rejen pedi.

'Coffee, they like very much.'

\subsection{Particle Movement Transformation}

In GL particle movement transformation is an optional rule. When the process of movement rule of particle ku deret 'go out', ku was 'inside', ku atas ' 'on top' is not applied, the result is still acceptable.

(20). Guru mungeni mured si keroh kuderet.

'The teacher asks students who make noise to go out'.

\begin{tabular}{ccccccc} 
DS & : & \multicolumn{3}{c}{ Guru mungeni kuderet } & mured si keroh. \\
Particle Move.: & $\downarrow$ & $\downarrow$ & $\downarrow$ & $\downarrow$ & $\downarrow$ \\
SI & $:$ & 1 & 2 & 3 & 4 & 5 \\
SC & $:$ & 1 & 2 & 4 & 5 & 3
\end{tabular}

SS

: Guru mungeni mured si keroh kuderet.

'Teacher asks students who make noisy to go out'.

Observe that when the rule is not applied, the result will remain acceptable as the form of the DS.

\subsection{Relative Movement Transformation}

Relative movement transformation in $\mathrm{GL}$ is a compulsory rule which must be applied to the DS of a sentence by moving a relative to the Comp position as in (21.a) and if the rule is not applied it will lead to an unacceptable sentence as in (21.b).

(21.a). Ini kero goreng singe penah we pangan.

'This is fried rice which he/she has ever eaten.'

DS : [CP [Ini kero goring] [CP [we nge pernah mangan kero goreng ini]]].

'This is fried rice he/she has eaten this fried rice' 
Relativization : [CP [Ini kero goring] \{CP [ we nge pernah pangan si ]]]

'This fried rice he/she has ever eaten which'

Relative Move.: Ini kero goreng singe pernah we pangan $t$

'This is fried rice which he/she has ever eaten $\boldsymbol{t}$

SS : : Ini kero goreng si nge pernah we pangan.

'This is fried rice which he/she has ever eaten.'

(21.b).

DS

: [CP [Ini kero goring] [CP [we nge pernah mangan kero goreng ini]]].

'This is fried rice he/she has eaten this fried rice'

Relativization : [CP [Ini kero goring] \{CP [ we nge pernah pangan si ]]]

'This fried rice he/she has ever eaten which'

Relative Move.: Not applied

SS : * Ini kero goreng we nge pernah pangan.

'This is fried rice he/she has ever eaten.'

\subsection{Premodification Transformation}

Premodification Transformation in GL is an optional rule. The position of a noun modifier is generally after the noun but in a certain condition the modifier may be prior to the noun. In other certain conditions the position of the modifier is optional, whether as a pre-modifier or post-modifier as in (22.a).

(22.a). Kude pacuen mera kalah atawa menang.

'Horse racing can lose or win.'

DS

: [CP [Pacuen kude] CP [mera kalah atawa menang]

'Racing horse can lose or win.'

Premodification : : [CP [kude pacuen] [CP [mera kalah atau menang]

'Horse racing can lose or win.'

SS

: Kude pacuen mera kalah atawa menang. (OR)

'Horse racing can lose or win.'

When the rule is not applied the result is still acceptable as in (22.b).

(22.b)

DS

: [CP [Pacuen kude] CP [mera kalah atawa menang]

'Horse racing can lose or win.'

Premodification : Not applied.

SS

: Pacuen kude mera kalah atawa menang.

'Horse racing can lose or win.'

\subsection{Adjective Preposing Transformation}

In $\mathrm{GL}$ adjective pre-posing transformation is also an optional rule. It means that the sentence will remain acceptable whether the rule is applied or not as in (23.b). Adjective 
pre-posing is a style in a certain conversation in order to explain or confirm the adjective phrase in the subordinate clause with the conjunction 'bierpe' 'Though' as in (23.a).

(23.a). Lungi pedi bierpe kupi oya, Uwin gere mera muminume.

'Very nice though the coffee is, Uwin does not want to drink it.'

DS

: Bierpe kupi oya lungi pedi, Uwin gere mere muminume.

'Though the coffee is very nice, Uwin does not want to drink it'

Adj. Preposing. : Lungi pedi bierpe kupi oya, Uwin gere mera muminume.

'Very nice though the coffee is, Uwin does not want to drink it.'

SS : Lungi pedi bierpe kupi oya, Uwin gere mera muminume.

'Very nice though the coffee is, Uwin does not want to drink it.'

(23.b).

DS

: Bierpe kupi oya lungi pedi, Uwin gere mere muminume.

'Though the coffee is very nice, Uwin does not want to drink it'

Adj. Preposing : Not applied.

DS : Bierpe kupi oya lungi pedi, Uwin gere mere muminume.

'Though the coffee is very nice, Uwin does not want to drink it.'

\subsection{Verb Preposing Transformation}

Verb pre-posing transformation in $\mathrm{GL}$ is an optional rule. A verb phrase can be preposed if it is required in order to emphasize the meaning as in (24).

Munekek nila aku pikir pakea i kulem.

'Fishing nila I think they are in the fishpond.'

DS

: Aku pikir pakea munekik Nila i kulem

'I think they are fishing Nila in the fishpond.'

Verb Preposing: Munekik Nila aku pikir pakea i kulem

'Fishing Nila I think they are in the fishpond.'

SS

: Munekik Nila aku pikir pakea i kulem.

'Fishing Nila I think they are in the fishpond'.

As it is an optional rule, it remains acceptable although the rule is not applied as in (24.b).

$(24, b)$.

DS

: Aku pikir pakea munekik Nila i kulem

'I think they are fishing Nila in the fishpond.'

Verb Preposing: Not applied.

SS : : Aku pikir pakea munekik Nila i kulem.

'I think they are fishing Nila in the fishpond'.

\subsection{Extra-position Transformation}

Extraposition transformation in $\mathrm{GL}$ is an optional rule. So, when the transformation is not applied the result is still acceptable. Extra-position transformation is to move a subordinate clause to the end of a sentence as in (25).

(25). Sara jemange enggeh si mungakui kesalahene. 
'A man has come who confesses his mistake'.

DS : [CP [ Sara jema] [CP [ si mungakui kesalahene] [VP nge enggeh ]]

$$
\text { 'A man who confesses his mistake has come' }
$$

Extraposition : [CP [ Sara jema $t_{x}$ [nge enggeh [CP [x si mungakui kesalahene]]]

'A man has come who confesses his mistake'

SS

: Sara jema nge enggeh si mungakui kesalahene.

'A man has come who confesses his mistake.'

\section{Conclusion}

Based on the discussions on the application of movement rules and evaluation of the status of the movement transformational rules in GL some conclusions can be deduced. All the twelve movement rules noted in Suhadi (2018) have proved relevant to apply to the syntactic constructions in GL. However, from the status of movement transformational rules, four movement rules in GL are compulsory covering Affix Hopping Transformation, Auxiliary Movement Transformation, Wh-movement Transformation and Relative Movement Transformation. The other eight are optional including Dative Movement Transformation, Passive Transformation, Topicalization Transformation, Particle Movement Transformation, Premodification Transformation, Adjective Preposing Transformation, Verb Preposing Transformation, and Extraposition Transformation. Unlike English in which there is a restricted movement transformational rule in terms of Particle Movement for a complex object, restricted rule is not found in GL.

\section{References}

Chomsky, N. (1965). Aspects of the theory of syntax. Cambridge, Massachusetts: The Massachusetts Institute of Technology.

Chomsky, N. (1981). Lectures on government and binding. The Pisa Lectures. Dordrecht: Foris Publications

Eades, Domenyk. (2005). Grammatical aspects of Gayo: language of Aceh, Sumatra. Canberra: Pacific Linguistics, Research School of Pacific and Asean Studies, Australian National University.

Kadir, Abdul. (1981). Cerita rakyat Gayo. Jakarta: Pusat Pembinaan dan Pengembangan Bahasa Departemen Pendidikan dan Kebudayaan.

Matin, Abdul. (2004). Research methods, statistics, IT and e-methods. New Delhi: Icon Publications Pvt. Ltd.

Ouhalla, Jamal. (1999). Introducing transformational grammar. From principles to parameters to minimalism. University of London, London: Oxford University Press.

Shaumiwaty. (2012). Phonology of Gayo language: an analysis of generative phonology.

Desertation. Medan: Universitas Sumatera Utara.

Suhadi, Jumino. (2018). An outline of English Transformational Grammar. Medan: Sastra UISU Press.

Zainuddin. (2012). Morphological system of Gayo language: Transformational Generative Analysis. Dissertation. Medan: Universitas Sumatera Utara. 